\title{
Parapharyngeal Space Tumors - "A Surgical Challenge"
}

\author{
Raj Nagarkar ${ }^{1}$, Sirshendu Roy ${ }^{1}$, Ashvin Wagh ${ }^{2}$ and Gauri Kokane ${ }^{2 *}$ \\ ${ }^{1}$ Department of Surgical Oncology, HCG Manavata Cancer Centre, India \\ ${ }^{2}$ Department of Head and Neck Surgical Oncology, HCG Manavata Cancer Centre, India
}

Submission: February 07, 2018; Published: February 16, 2018

*Corresponding author: Gauri Kokane, Fellow HCG Manavata Cancer Centre, Mumbai Naka Nashik, India, Tel: 9108424064382;

Email: gaurikkn@gmail.com

\begin{abstract}
Parapharyngeal space tumors are rare entity. Overall incidence is less than $0.5 \%$. These tumors are divided into prestyloid and post styloid tumors. Salivary gland neoplasma are common in prestyloid compartment whereas Neurogenic tumors in post styloid compartment. As these tumors are painless and does not express signs and symptoms at early stage, diagnosis of such tumors needs critical evaluation. Anatomic complexity of PPS makes surgical excision more challenging. We have reported 4 cases of parapharyngeal space tumors over a period of 10 years.

Keywords: Parapharyngeal; Schwannoma; Paraganglioma; Neurogenic; Transcervical
\end{abstract}

\section{Background}

Parapharyngeal space is an inverted pyramid from base of the skull to hyoid bone. It is bounded medially by pharynx, anteriorly pterygomandibular raphe, posterolaterally carotid sheath, posteromedially retropharyngeal space, laterally above the level of mandible it is bounded by ramus of mandible, deep lobe of parotid and medial pterygoid muscle, below the level of mandible; it is bounded by posterior belly of diagastric muscle. It is divided into prestyloid and poststyloid compartment by aponeurosis of zuckercandle and testus [1]. $80 \%$ of the PPS tumours are benign while $20 \%$ are malignant [2]. Incidence of parapharyngeal space tumors is less than $0.5 \%$ [3]. Majority of the tumours are slow growing, painless and progressive in nature. If untreated might result in severe life threatening complications like airway obstruction and cranial nerve deficit resulting in significant morbidity. Systematic diagnostic evaluation plays an important role in diagnosis. Surgical excision has Pivotal significance in PPS tumors. We have identified and reported four cases of parapharyngeal space tumors at our centre over a period of 10 years.

\section{Case Description}

\section{Case 1}

29 year old male presented with complain of painless lateral neck swelling since 3 months. There was no history of dysphagia, Hoarseness of voice. There was no cranial nerve involvement. FNAC showed spindle cell tumor. On MRI there was 50x $37 \mathrm{~mm}$ well circumscribed lesion over left side of neck suggestive of schwannoma. Surgical Excision of the tumor was done using transcervical approach (Figure 1). There was no intra-operative complication. ICA, ECA, Vagus nerve and IJV were identified and preserved. Tumor was excised completely (Figure 2). Post operatively there was reduction in high pitch sounds. Origin of tumor from vagus nerve was confirmed intra-operatively. Microscopic picture revealed presence of mixed Antoni A and Antoni B cells concluding to the microscopic features of schwannoma.

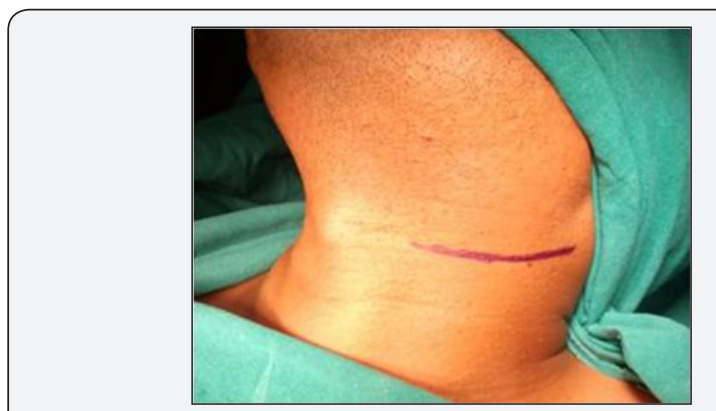

Figure 1: Transcervical approach for parapharyngeal space tumors.

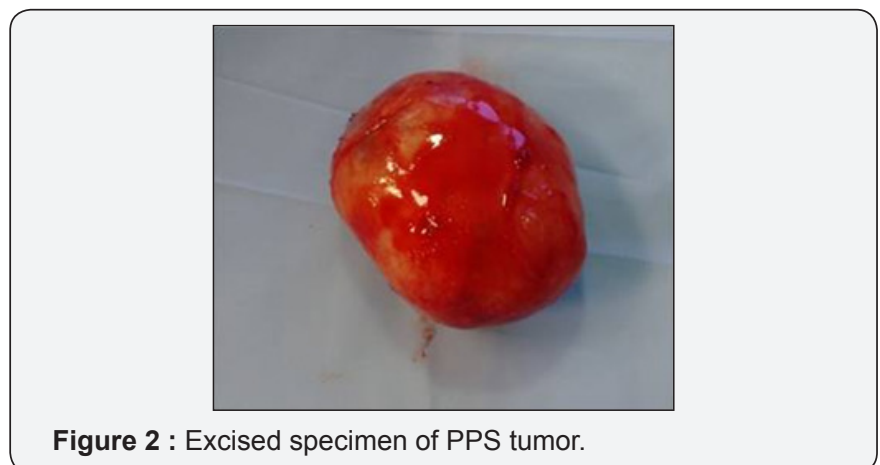




\section{Case 2}

34 year old female presented with painless swelling over right side of neck. CT neck showed $64 \times 46 \times 35 \mathrm{~mm}$ lesion in the carotid space compressing right IJV and displacing it anterolaterally (Figure 3). Superiorly it was extended up to carotid canal. Differential diagnosis includes paraganglioma in view of intense enhancement of lesion and vagal schwannoma in view of displacement pattern of vessel. FNAC was suggestive of spindle cell tumor. Intraoperatively there was rupture of internal carotid artery which was repaired with 6-0 ethilon, vagus nerve was also sacrificed due to the severe adherence of the tumor to the nerve.

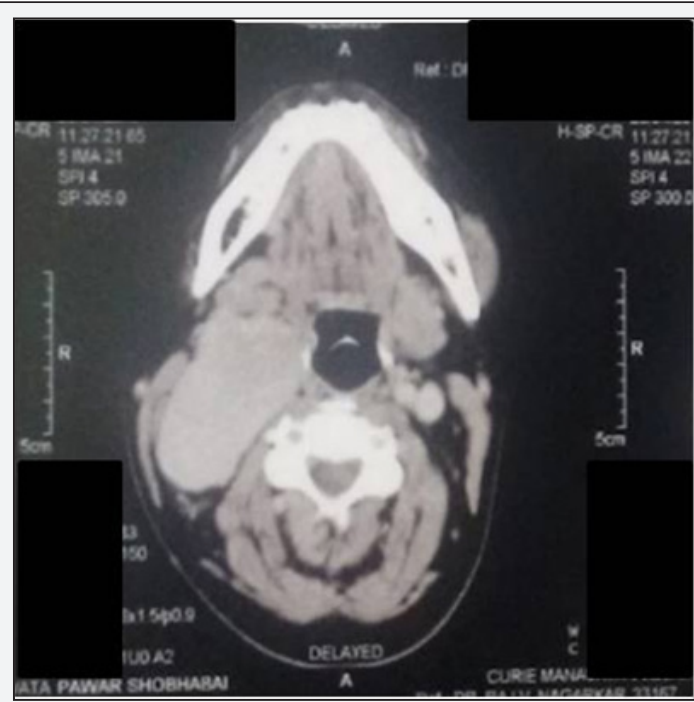

Figure 3 : CT scan of neck showing $64 \times 46 \times 35 \mathrm{~mm}$ lesion in the carotid space compressing right IJV and displacing it anterolaterally.

\section{Case 3}

24 year old female complains of painless progressive swelling with dysphagia to solids and liquids since 4 yrs. CT scan showed heterogeneously enhancing lesion $85 \times 31 \mathrm{~mm}$ with retrosternal extension displacing major vessels laterally. Intraoperatively transcervical incision was taken and tumor was dissected to free it from the major vessels and nerves and it was removed in to (Figure 4).

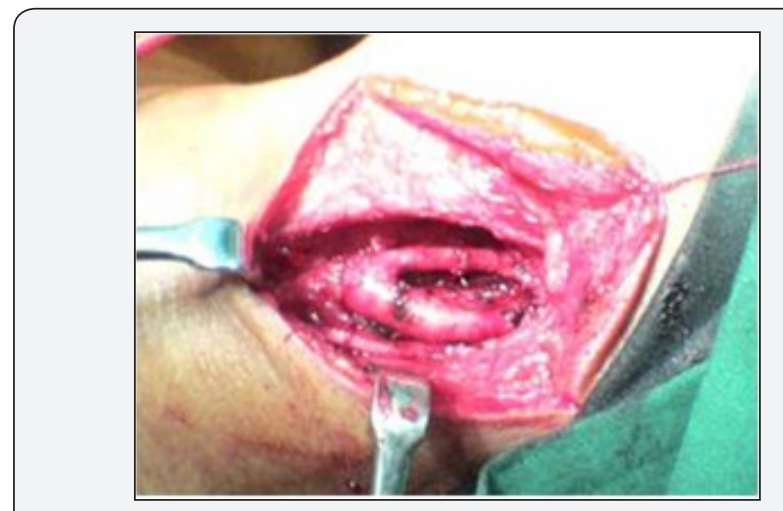

Figure 4 : Carotid Bifurcation after excision of tumor.

\section{Case 4}

40 year female patient presented with swelling of left submandibular region since 1 month (Figure 5). FNAC showed spindle cell tumor, USG showed $41 \times 39 \mathrm{~mm}$ Heterogenous mass and left submandibular gland. CT Scan Showed $4.5 \mathrm{~cm}$ enhancing well circumscribed lesion, left submandibular gland and another $1.3 \times 1 \mathrm{~cm}$ lesion adjacent to it. No dysphagia or hoarseness of voice, intra-operatively Hypoglossal nerve was sacrificed. Lingual nerve was identified and preserved. Histopathology report showed neurogenic tumour i.e. schwannoma.

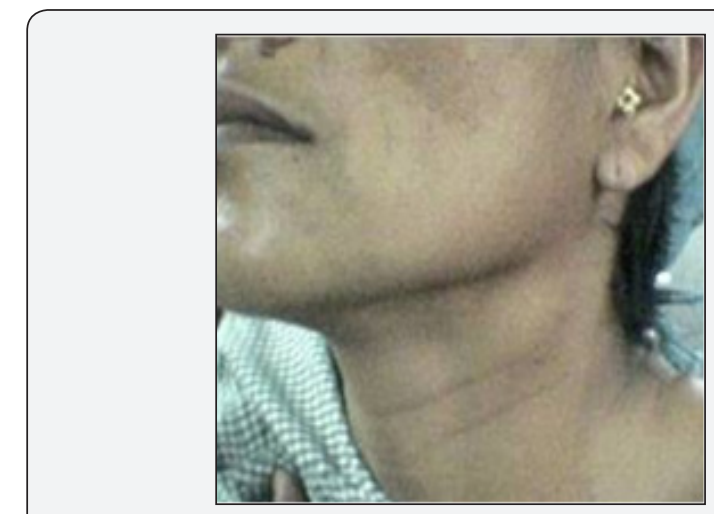

Figure 5 : Left Submandibular swelling.

\section{Discussion}

Para-pharyngeal space (PPS) tumors are very rare. We have identified 4 patients after reviewing 10 years retrospective data of all head and neck tumors presented at Manavata curie cancer centre Nashik. Incidence of parapharyngeal space tumors at our institute was $0.004 \%$. Overall incidence of these tumors is less than $0.5 \%$. These tumors are slow growing, painless and patients express at later stage when the size become considerably large. Usually patients are asymptomatic but may exhibit dysphagia or hoarseness of voice. In our 4 patients only one patient had dysphagia to solids and liquids rest of the patients were asymptomatic [4,5]. $80 \%$ of the tumors arising in this region are benign [2]. Pleomorphic adenoma is the most common tumor of prestyloid compartment where poststyloid tumors are mostly neurogenic like shwannoma, paraganglioma, neurofibroma, hemangiomas etc. Chordomas, lypomas, lymphomas, chemodectomas, rhabdomyomas, chondrosarcomas, desmoid tumours, ameloblastomas, amyloid tumours, ectomesenchymomas, fibrosarcomas and plasmocytomas have also been reported [2].

Diagnosis of these tumors is difficult as they are asymptomatic. Diagnostic evaluation constitutes CT scan and MRI to clearly define the extent of the tumor mass. Arteriography also plays a significant role to assess vascular compression. In our identified cases CT scan was performed in 3 cases and MRI in one case. MRI has been shown to gives better dimensions of the parapharyngeal space tumors. Advantage of MRI is, it distinguishes tumor from Muscular structures and give better dimentions of the tumor [6]. 
Arteriography was not performed in any of our cases. Once the nonvascular nature of tumor is confirmed by radio-imaging, FNAC can be performed for definitive diagnosis. FNAC is accurate in $90-95 \%$ of the cases and helps in surgical planning [7]. Limited role is explained in post styloid compartment. We performed FNAC in all our patients and it was conclusive $[8,9]$.

Schwannoma may arise at any age but in our institute patient's age ranged from 3 rd to 4 th decades of life. There is no gender predilection. Schwannoma may be of two types histologically consisting of either Antoni A cells or Antoni B cells. We had two patients with Antoni A cells and other one was of mixed variety [10]. Paragangliomas are tumors of autonomic nervous system. Head and neck paragangliomas are unique in its variety as they don't release catecholamines. Incidence of paraganglioma is 1 in 30,000 cases [11]. Histopathological picture shows two types of cells; Chief cells and sustantecular cells. One of our patient's histological features were identical to it.

Surgical management of parapharyngeal space tumors is very challenging owing to anatomic complexity of the space and vicinity of the tumor with major neurovascular structures. There are 7 different approaches described for PFS tumors. Transcervical, Transcervical- transparotid, Transoral-transcervical approach, Extended approach, Transcervical-mandibulotomy aaproach, Transcervical-transmastoid approach have been explained [12]. $4 \mathrm{~cm}$ is the limit for radical tumour excision with the transcervical approach without mandibulotomy. For a safe and radical resection of tumours $>4 \mathrm{~cm}$ the "swing" approach or the transmandibular with a double osteotomy is required [2]. We used transcervical approach without mandibulotomy in all cases. Accesiblity was compromised in larger tumors but we could enucleate entire tumor without much difficulty. ICA was ruptured in one case but it was managed. Minimal accessibility may be a compromise but there is less surgical morbidity and post op recovery is faster in our experience.

Complications after surgical management are unavoidable. Expected complications are due to sacrifice of cranial nerves. There may be unexpected neurological complications in spite of preservation of nerves like first bite syndrome, Trismus, facial nerve weakness, orocutaneous fistula, Seroma. We experienced loss of high pitched sounds in two of our patients and there was hypoglossal nerve palsy as hypoglossal nerve was sacrificed in one case.

\section{Conclusion}

CT scan or MRI should always be performed in order to distinguish prestyloid from poststyloid lesions and assessment of the extension of the tumour and its relationship with adjacent structures. Trans-cervical approach is safe and should be the first choice for large tumors; other approaches are reserved for selected cases.

\section{Clinical Significance}

These are painless slow growing non malignant tumors with very less incidence of recurrance. Management of PPS tumors is challenging for surgeons. Neurological and Surgical complications should always be explained to patients preoperatively. Preoperative assessment and careful surgical manipulation are of utmost importance.

\section{References}

1. Javaid Khan MI, Ali MM, Abbas T (2002) Transcervical Excision Parapharyngeal Space Masses. Ann King Edward Med Coll 8: 59-62.

2. Bozza F, Vigili MG, Ruscito P, Marzetti A, Marzetti F (2009) Surgical management of parapharyngeal space tumours: results of 10-year follow-up. Acta Otorhinolaryngol Ital 29(1): 10-15.

3. Batsakis JG, Sneign N (1989) Parapharyngeal and retropharyngeal space diseases. Ann Otol Rhinol Laryngol 98(4 Pt 1): 320-321.

4. Popovski V (2007) Massive deep lobe parotid neoplasms and parapharyngeal space-occupying lesions: contemporary diagnostics and surgical approaches. Prilozi 28(1): 113-127.

5. Zitsch RP, Patenaude B, Tidmore T (2007) An extraoral parapharyngeal space approach via vertical ramus osteotomy. Am J Otolaryngol 28(5): 330-333.

6. Tincani AJ, Martins AS, Altemani A, Scanavini RC, Barreto G, et al. (1999) Parapharyngeal space tumors: considerations in 26 cases. Sao Paulo Med J 117(1): 34-37.

7. Acosta L, Montalvão P, Magalhães M, Olias J, Santiago N (2002) Parapharyngeal space tumors. Our experience. I.P.O. Francisco Gentil, Lisbon. Acta Otorrinolaringol Esp 53(7): 485-490.

8. Carew JF, Spiro RH, Singh B, Shah JP (1999) Treatment of recurrent pleomorphic adenoma of the parotid gland. Otolaryngol Head Neck Surg 121(5): 539-542.

9. Leonetti JP, Marzo SJ, Petruzzelli GJ, Herr B (2005) Recurrent pleomorphic adenoma of the parotid gland. Otolaryngol Head Neck Surg 133(3): 319-322.

10. Maran AGD (1987) Benign diseases of the neck. Scott Brown's Otolaryngol 5: 283-300.

11. Wasserman PG, Savargaonkar P (2001) Paragangliomas: classification, pathology, and differential diagnosis. Otolaryngol Clin North Am 34(5): 845-862,

12. Cohen SM, Burkey BB, Netterville JL (2005) Surgical management of parapharyngeal Space masses. Head Neck 27(8): 669-675. 
This work is licensed under Creative Commons Attribution 4.0 Licens

DOI: 10.19080/JHNSS.2018.02.555587

\section{Your next submission with Juniper Publishers} will reach you the below assets

- Quality Editorial service

- Swift Peer Review

- Reprints availability

- E-prints Service

- Manuscript Podcast for convenient understanding

- Global attainment for your research

- Manuscript accessibility in different formats

( Pdf, E-pub, Full Text, Audio)

- Unceasing customer service

Track the below URL for one-step submission https://juniperpublishers.com/online-submission.php 